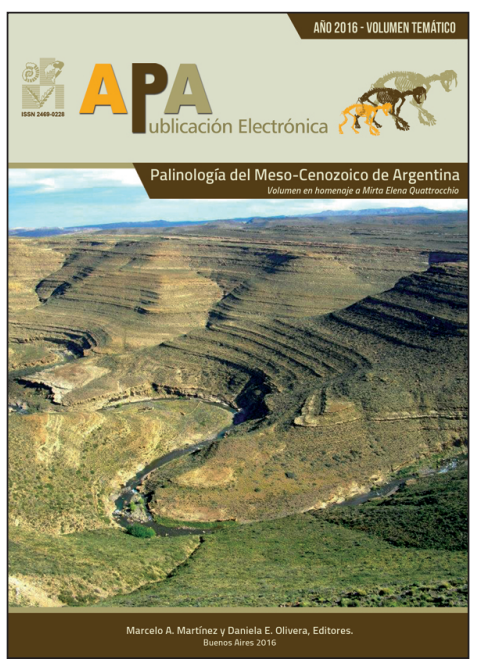

\title{
MULTI-PROXY ANALYSIS OF LATE QUATERNARY SEDIMENTS IN THE LOWER BASIN OF THE QUEQUÉN SALADO RIVER (BUENOS AIRES PROVINCE, ARGENTINA): AN UPDATE
}

SILVIA C. GRILL1,2

ANA L. FERNÁNDEZ ${ }^{1}$

1Departamento de Geología, Universidad Nacional del Sur, San Juan 670, (B8000ICN) Bahía Blanca, Argentina.

${ }^{2}$ Instituto Geológico del Sur (INGEOSUR), San Juan 670, (B8000ICN) Bahía Blanca, Argentina.

Recibido: 1 de septiembre de 2015 - Aceptado: 9 de mayo de 2016

Para citar este artículo: Silvia C. Grill and Ana L. Fernández (2016). Multi-proxy analysis of Late Quaternary sediments in the lower basin of the Quequén Salado River (Buenos Aires Province, Argentina): an update. En: M. Martínez y D. Olivera (Eds.), Palinología del Meso-Cenozoico de Argentina - Volumen en homenaje a Mirta Elena Quattrocchio. Publicación Electrónica de la Asociación Paleontológica Argentina 16 (2): 129-147.

Link a este artículo: http://dx.doi.org/10.5710/PEAPA.09.05.2016.84

DESPLAZARSE HACIA ABAJO PARA ACCEDER AL ARTÍCULO

Asociación Paleontológica Argentina Maipú $6451^{\circ}$ piso, C1006ACG, Buenos Aires República Argentina Tel/Fax (54-11) 4326-7563 Web: www.apaleontologica.org.ar

Otros artículos en Publicación Electrónica de la APA 16(2):

\section{Borel, Guler, Navarro \& Astini}

ANCIENT COASTAL ENVIRONMENTS IN A MAASTRICHTIAN - ?PALEOCENE ATLANTIC SHORELINE:

A PHYTOPLANKTON APPROACH

\section{Prieto}

ANÁLISIS E INTERPRETACIÓN DE REGISTROS PALINOLÓGICOS DE SUCESIONES ALUVIALES DE LA REGIÓN PAMPEANA: REVISIÓN E IMPLICANCIAS PARA LA RECONSTRUCCIÓN DE LA VEGETACIÓN Y EL CLIMA DURANTE EL PLEISTOCENO TARDIO - HOLOCENO

\section{Candel \& Borromei}

REVIEW OF THE PALAEOENVIRONMENTAL RECONSTRUCTION OF LATE QUATERNARY MARINE SEQUENCES, TIERRA DEL FUEGO (ARGENTINA) 


\title{
MULTI-PROXY ANALYSIS OF LATE QUATERNARY SEDIMENTS IN THE LOWER BASIN OF THE QUEQUÉN SALADO RIVER (BUENOS AIRES PROVINCE, ARGENTINA): AN UPDATE
}

\author{
SILVIA C. GRILL1,2 AND ANA L. FERNÁNDEZ1 \\ Departamento de Geología, Universidad Nacional del Sur, San Juan 670, (B8000ICN) Bahía Blanca, Argentina. \\ 2Instituto Geológico del Sur (INGEOSUR), San Juan 670, (B8000ICN) Bahía Blanca, Argentina. sgrill@criba.edu.ar; afernandez@uns.edu.ar
}

\begin{abstract}
Two fossil sections (Late Quaternary), and a group of modern samples analyzed through pollen and non-pollen palynomorphs, enabled the reconstruction of the palaeoclimatic and palaeoenvironmental conditions of the lower basin of the Quequén Salado River (Buenos Aires Province). The study was complemented with analysis of sedimentology, malacofauna, ostracods, diatoms, and mammal and archaeological remains. For the Late Pleistocene, the scarce presence of microfossils, associated with eolian palaeoenvironments, allowed inferring arid/extremely arid climate conditions. In the Pleistocene/Holocene boundary, evidence of a pedogenetic event suggests a brief lapse of climatic stability. Pollen indicates the development of a halophyte steppe, which remained in the area until the Middle Holocene. During the Early Holocene $(8,173 \mathrm{cal}$ yr B) the sedimentology, malacofauna and microfossils evidenced a sea level rise. This event ended with the establishment of a brackish lacustrine body towards the Middle Holocene. After that, a pulse characterized by high humidity levels, indicate the replacement of the halophyte steppe by a gramineous steppe. Following that pulse during the 6,799 cal yr BP 5,603 cal yr BP lapse, the microfossils showed considerable variability, thus reflecting an alternation between relatively more humid and dry pulses. Evidence indicates that during the Late Holocene ( 1,000 yr BP) modern ecosystems began to settle in the lower basin of the Quequén Salado River. Two global climate changes, the Medieval Climate Optimum (823 cal yr B- 690 cal yr B) and the Little Ice Age (389 cal yr B) were inferred through pollen and faunistic remains at $\mathrm{QS}_{1}$ Archaeological Site.
\end{abstract}

Key words. Palaeoenvironmental-palaeoclimatic changes. Late Quaternary. Quequén Salado River. Argentina.

Resumen. ANÁLISIS MULTI-PROXY DE SEDIMENTOS DEL CUATERNARIO TARDÍO EN LA CUENCA INFERIOR DEL RÍO QUEQUÉN SALADO (PROVINCIA DE BUENOS AIRES, ARGENTINA). UNA ACTUALIZACIÓN. El análisis de microfósiles polínicos y no polínicos de dos secciones fósiles de edad Cuaternario tardío y de un conjunto de muestras actuales, permitió evaluar las fluctuaciones paleoambientales y paleoclimáticas en la cuenca inferior del río Quequén Salado (provincia de Buenos Aires). El aporte de la sedimentología, malacofauna, ostrácodos, diatomeas, restos de mamíferos y arqueológicos, complementó el estudio efectuado. Para el Pleistoceno Tardío los escasos microfósiles hallados, asociados a paleoambientes eólicos permitieron inferir condiciones climáticas áridas/extremadamente áridas. En el límite Pleistoceno/Holoceno, evidencias pedogenéticas se asociaron a un breve episodio de estabilidad climática, el polen reflejó el desarrollo de comunidades halófitas las cuales permanecieron en el área hasta el Holoceno Medio. Durante el Holoceno Temprano (8,173 cal. años AP), el ascenso del nivel marino manifestado a través de la sedimentología, malacofauna y microfósiles, culminó con la instalación de un cuerpo lagunar salobre hacia el Holoceno Medio. Con posterioridad, un pulso más húmedo inferido a partir del reemplazo de la estepa halófita por graminosa, fue seguido de un lapso (6,799 cal. años AP-5,603 cal. años AP) con alternancia de períodos húmedos y secos evidenciados a partir de una importante variabilidad en las asociaciones polínicas, los microfósiles no polínicos (MNPs), ostrácodos y diatomeas. Para el Holoceno Tardío se habrían establecido en el área los ecosistemas actuales, registrándose, en el Sitio Arqueológico QS 1 , dos cambios climáticos globales: Óptimo climático Medieval (823 cal. años AP-690 cal. años AP) y La Pequeña Edad de Hielo (389 cal. años AP).

Palabras clave. Cambios paleoambientales-paleoclimáticos. Cuaternario tardío. Río Quequén Salado. Argentina.

CONTINENTAL deposits are usually characterized by unconformities and marked facies changes. Land-based records are significantly more useful than deep-sea records in terms of spatial detail and sensitivity. Palaeoenvironmental studies have, to some degree, been avoided on arid lands due to their sparse vegetation, poor pollen production, high rates of deposition in most continental basins, predominantly clastic sediments, and abundance of carbonate and sulphate cements (Horowitz, 1992). However, these types of lands are more sensitive than temperate or tropical ones for regis- 
tering environmental changes, which enables a more accurate reconstruction of global trends (Horowitz, 1992). Thus, the southern Pampean Region of Argentina clearly exemplifies the relevance of multidisciplinary studies of aridsemiarid landscapes in reconstructing the evolution of past climates (Quattrocchio et al., 2008).

In this region, most of the palaeoenvironmental and palaeoclimatic reconstructions of the Late Quaternary were based on the study of sections exposed along river valleys and loess sequences. Through pollen analysis Borromei (1995, 1998) studied the climatic and environmental fluctuations since the Late Pleistocene-Holocene in the Sauce Grande Valley. Grill $(1995,1997)$ conducted similar studies in the Napostá Grande stream basin, and Quattrocchio et al. (1988, 1998, 2008) carried out multi-proxy studies (sedimentology, palaeontology and micropalaeontology) in the main superficial fluvial systems southwest of Buenos Aires Province. Stutz et al. (1999) showed the evolution of the vegetation during the Holocene, affected by eustatic fluctuations at La Ballenera Creek.

A few studies focus on lacustrine records, among which Vilanova et al. (2006) stands out as it presents similar studies to those previously mentioned for the Villa Gesell headland. Fontana (2005) reconstructed the palaeoenvironments and vegetation of the Holocene in the locality of Monte Hermoso (La Olla 1 and Sauce Grande Lagoon Sites), based on pollen content, calcareous microfossils (ostracods and foraminifers) and plant microfossil remains in the sediments.

In addition, several palaeoenvironmental and palaeoclimatic reconstructions associated with archaeological sites have been carried out in rivers, streams and lacustrine bodies of south-western Buenos Aires Province (Zavala et al., 1992; Madrid et al., 2002; March et al., 2003; Bayón et al., 2004; Grill et al., 2007, 2010; Gutiérrez and Martínez, 2008; Martínez et al., 2009a-c; among others).

Regarding the river valleys of the southern Pampean Region, they have sporadically functioned as zones of sediment transport from the ranges (Sierras Australes) to the continental shelf (Zavala and Quattrocchio, 2001, p. 32). Field evidence shows that these valleys, carved sometime in the Pleistocene, have acted for a long time as dried depressed areas, subject to no deposition or to aeolian depo- sition, or have been drained by local, ephemeral streams (Zavala and Quattrocchio, 2001). It is estimated that the age of the valley filling, associated with stages 2, 3 and 4 (Zavala and Quattrocchio, 2001, p. 35-36), is Early to Middle Pleistocene, coinciding with an interglacial period, extending until the Late Holocene, when the final incision of the streams occurred. A good example is the Quequén Salado River, one of the most important fluvial systems in southwestern Buenos Aires (SE of Pampean Region).

Conversely, sequence stratigraphy models that attempt to relate the incision of valleys with relative sea-level falls might not be applied to the fluvial systems of the southern Pampean Region. For the LGM (Late Glacial Maximum), when the sea level was $120 \mathrm{~m}$ lower than today (Alley, 1990), there is no evidence of incision in the region (there is evidence of ephemeral deposits and palaeosoils), and it was probably the climate that played a major role in shaping the landscapes (Zavala and Quattrocchio, 2001). Hence the importance of reconstructing palaeoclimates through different "proxy data".

The main aim of this contribution is to provide a palaeoenvironmental and palaeoclimate reconstruction of the lower basin of the Quequén Salado River (Pampean Region) from the Late Pleistocene to the present. The studies performed include multiproxy analyses: sporomorphs (spores and pollen grains), organic-walled marine microplankton, NPMs (non-pollen microfossils), sedimentological, palaeontological (malacofauna, ostracods and diatoms) and archaeological studies. Among previous geological and palaeontological research conducted in the study area, Frenguelli (1928); Farinati and Zavala (1995); Martínez and Gutiérrez Tellez (1998) and Alberdi et al. (1995) stand out. The only palynological studies conducted in this basin correspond to one of the authors of the present work (Grill, 2003; Grill and Lamberto, 2006 and Grill et al., 2010).

Grill (2003) analyzed the changes in vegetation and eustatic fluctuations from the Late Pleistocene to the present in the Estancia Thomas Profile. Grill and Lamberto (2006) studied the palynofacies in seven modern environments of the lower Quequén Salado River basin, along with the relationship between pollen and vegetation. Native and exotic elements of the existing flora were differentiated with special emphasis placed on taphonomy for the total paly- 
nological organic matter analysis. In Grill et al. (2010), palaeoenvironmental and palaeoclimatic fluctuations during the last 1,000 yr BP were analyzed in a stratigraphic sequence associated with a human settlement (QS, Archaeological Site).

In the present contribution, the previously mentioned results (fossil: Estancia Thomas Profile and QS 1 Archaeological Site, and modern samples) will be integrated, updated and reinterpreted for the first time. In addition, it is worth mentioning that new radiometric dating is provided for the most complete fossil sequence studied in this work (Estancia Thomas Profile). In turn, the global climate fluctuations inferred for the last 1,000 yr BP in $\mathrm{QS}_{1}$ Archaeological Site are compared with data from recently studied archaeological sites in the lower basin of the Colorado River (300 km south of the Quequén Salado River) (Fernández, 2012).

Finally, it is important to highlight the relevance of the use of "modern analogues" from the vicinity of the studied fossil sequences, in the reconstruction of the evolution of past environments and climates. In this sense, modern samples from the Bahía Blanca Estuary, approximately $200 \mathrm{~km}$ south of the studied area (Grill and Guerstein, 1995) were used in addition to the modern samples from the lower basin of the Quequén Salado River. The data obtained from this group of samples were extremely relevant for the environmental reconstruction of the area, as they were obtained at a modern estuarine environment, which is relatively close to the fossil sequence affected by estuarine fluctuations during the Holocene.

\section{REGIONAL SETTING}

\section{Geomorphology}

The Quequén Salado River originates between two structural heights comprising the "Positivo Bonaerense" (Tandilia to the north and Ventania to the south). Its drainage area corresponds to the Pampa Interserrana (Frengüelli, 1950), which presents, just like the rest of the Pampean Region, a scarcely elevated landscape, typically flat, with no significant variations in height. It runs for 162 $\mathrm{km}$ and flows into the Atlantic Ocean as an estuary (Marini, 2002). It can be compared with integrated drainage networks (González Uriarte, 1984) or with R1 (main drainage networks), currently active networks flowing from the Serrano or Interserrano System to the Atlantic Ocean (Zavala et al., 2005). It is divided into four basins: High Basin, Sierras de Pillahuincó Basin, Middle Basin and Lower Basin (Marini, 2002) (Fig. 1.1). The Lower Basin, concerning the present work (Fig. 1.2), can be associated with Zone 2 (Schumm, 1977), where the system acts as a sort of sediment "by pass". The Quequén Salado River has permanent flow, with autochthony in the high and middle basins, and allochthony in the lower basin. Further geomorphologic features of the area include three dune belts (mobile, semifixed and fixed, associated with interdune depressions) and small lacustrine bodies.

\section{Climate and Vegetation}

Buenos Aires Province occupies the central-eastern portion of Argentina, between $33^{\circ}$ and $41^{\circ}$ south latitude. Consequently, it lies within the belt of temperate climate (Burgos, 1968). Because of its position in Argentina and South America, the oceanity factor is significant (Burgos, 1968), moderating the climate, especially near the coast. Continentality features intensify away from the coast (Verettoni and Aramayo, 1976).

As regards the pattern of winds, both in warm and cold months, the NE-SW trend is due to the activity of the South Atlantic and South Pacific anticyclones. Subantartic cold air masses from the SW and warm air masses from the north, caused by the occasional recession of the Pacific anticyclone (Burgos, 1968) also affect the climate of Buenos Aires Province. In the study area, the prevailing winds come from the north, followed by the NW (Marini, 2002). Winds from the east are less frequent but reach up to $133 \mathrm{~km} / \mathrm{h}$. The annual rainfall in the area of Marisol Beach (19951999 ) is $668.6 \mathrm{~mm}$, and the mean annual temperature for the same period is $14.8^{\circ} \mathrm{C}$ (Marini, 2002).

From a phytogeographic perspective, the study area is located in the Pampean Province (Austral Pampean District) (Cabrera, 1976). According to the census conducted by Grill and Lamberto (2006), in the lower basin of the Quequén Salado River, the pristine vegetation has been profoundly modified by crops, grazing and anthropic forests. Out of the 56 plant species counted, 37 are native and the rest are introduced. 

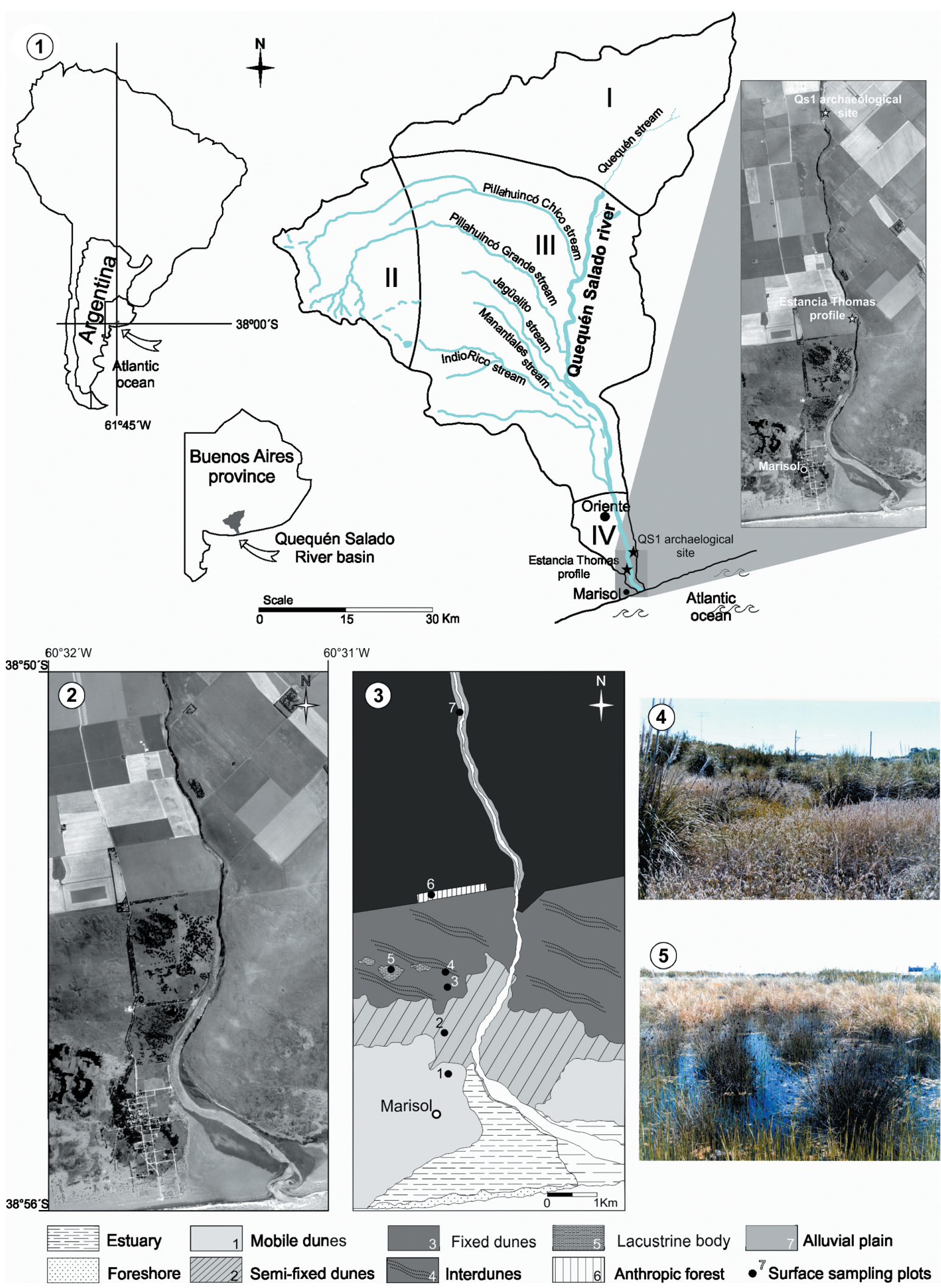

Figure 1. 1, Sectorization of the Quequén Salado River basin according to the dynamic of each area (modified from Marini, 2002): 1-High basin 2- Pillahuincó Hill 3- Middle basin and 4-Lower basin. In shaded area location of the study sites. 2, Study area. 3, Location map of surface sampling. 4, Present environment of interdune pond. 5, Present environment of lacustrine body. 
TABLE 1. Vegetation and pollen spectra from surface samples of Quequén Salado river.

\begin{tabular}{ccc}
\hline Sampling units & Vegetation types & Pollen \\
Mobile dunes & $\begin{array}{c}\text { Calycera crassifolia, Sporobolus rigens, } \\
\text { Cortaderia selloana }\end{array}$ & Sterile \\
Semi-fixed dunes & Tamarix gallica, Sporobolus rigens, \\
Cortaderia selloana & Tamarix gallica (80\%) \\
Fixed dunes & Poaceae (10\%)
\end{tabular}

All seven environments (Fig. 1.3) characterized in this study by their plant communities and by the pollen content of their sediments are shown in Table 1. The interdune depressions and the lacustrine bodies are illustrated in Figures 1.4 and 1.5 , respectively.

\section{STRATIGRAPHY AND AGE}

Reig (1957) defined the Irene Formation at the margins of the Quequén Salado River, between the localities of Irene and Oriente, which, according to Kraglievich (1960), is composed of reddish silts and clays with remains of impactites (Schultz et al., 2004). Verzi et al. $(2003,2008)$ stated that the levels of this Formation that yielded remains of the Octodontidae rodent Xenodontomys ellipticus (Kraglievich, 1927), can be assigned to the Late Miocene.

The Estancia Thomas Profile (38 $53^{\prime} \mathrm{S}, 60^{\circ} 32^{\prime} \mathrm{W}$ ) represents the most complete stratigraphic column of the present study. It is located at the right margin of the river, $8 \mathrm{~km}$ from its mouth (Fig. 2.1). It is $4.50 \mathrm{~m}$ thick and is represented by four units, separated by unconformities (Farinati and Zavala, 1995). Three of them have a continen- tal origin: Middle and Upper Sections of the Agua Blanca Sequence (Zavala and Quattrocchio, 2001), and Chacra La Blanqueada Formation (Rabassa, 1989), and one has marine origin: Las Escobas Formation (Fidalgo et. al., 1973).

Due to its stratigraphic position and regional correlation, the lower section of the profile has been assigned to the Late Pleistocene. Towards the top of this section a pedogenetic event is evidenced through the record of part of its "A" horizon (Farinati and Zavala, 1995). Radiocarbon dating yielded 8,195-8,396 cal. yr BP for these levels. This dating is presumed to be the minimum age due to the rejuvenation of the sediments with soil development. In consequence it was not included in the palaeoenvironmental and palaeoclimatic reconstruction of the area. The sediments belonging to the Holocene-historical times have four radiocarbon datings covering the 8,173-207 cal. yr BP lapse. The section finishes with a paleosoil, hence, the dating (207 cal. yr BP) is considered as the minimum age due to the effect caused by the pedogenetic event.

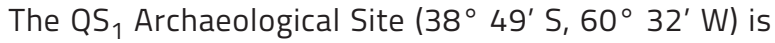
located at the left margin of the Quequén Salado River, 11 

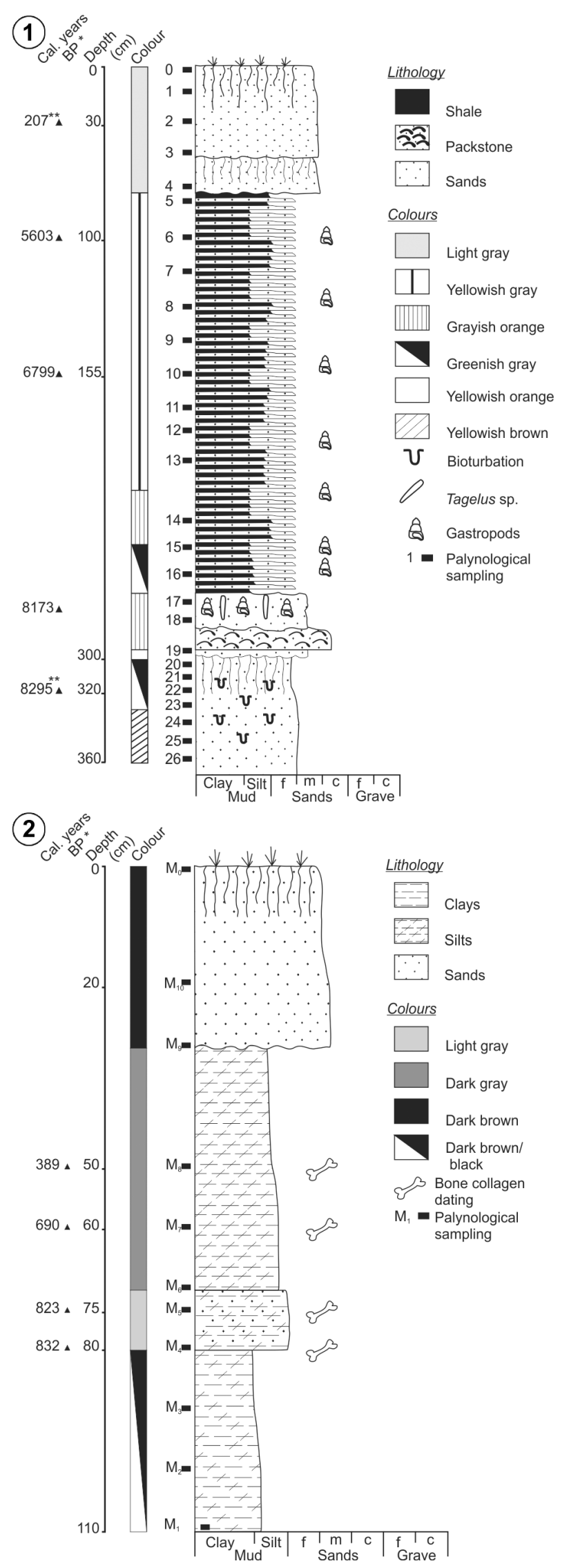

km from the Atlantic coast (Fig. 2.2). It is represented by $1.10 \mathrm{~m}$ of continental sediments, assignable to the Chacra La Blanqueada Formation (Rabassa, 1989; Zavala and Quattrocchio, 2001). This section has four radiocarbon datings covering the last $1,000 \mathrm{yr} \mathrm{BP}$.

\section{MATERIAL AND METHODS}

The fossil pollen records (Estancia Thomas Profile and QS 1 Archaeological Site; Figs. 3.1 and 3.2 respectively) were interpreted based on environmental data using the modern pollen-vegetation-climate relationship as analogue. This information was taken from Grill and Lamberto, 2006; Grill and Guerstein, 1995 (Figs. 4.1 and 4.2 respectively) and Prieto, 1996. Palynological analysis, involved identifying plant communities, their fluctuations through time and their classification into pollen assemblage zones. Relative sea level changes were evaluated in Estancia Thomas Profile, taking into account the microplankton preserved in marine deposits, as well as changes of coastal vegetal communities. Non-pollen microfossils (NPMs) were used to complement the palaeoenvironmental reconstruction, especially in the case of sterile palynological samples or when the samples did not reach the minimum number of pollen grains for analysis.

The NPMs remains found in QS-2c Pollen Subzone (Estancia Thomas Profile) represent the most conspicuous forms in the profile, and they are illustrated in Figure 5. The "multi-proxy" analysis performed in the lower basin of the Quequén Salado River, with its corresponding palaeoenvironmental and palaeoclimate inferences, are illustrated in Table 4.

The radiocarbon datings presented in this work were performed at the NSF-Arizona Laboratory (Tab. 2). All the radiocarbon ages are expressed as years BP (years Before Present) and cal. years BP (calibrated years Before Present) with a precision of $\pm 2 \sigma$ (Stuiver et al., 2005) (Tab. 3), and the mean calibrated ages are used in the text.

Figure 2. Stratigraphic profiles with details of the palynological sampling. 1, Estancia Thomas Profile (modified of Farinati and Zavala, 1995) (*average age calibrated). 2, QS 1 Archaelogical Site profile (from Grill et al., 2010). 
TABLE 2. Radiocarbon datings presented in this work.

\begin{tabular}{cccccc}
\hline Depth & Laboratory Code & Sample & ${ }^{14}$ Cyears $B P$ & Cal. Years $B P^{*}$ & $\delta^{13}$ CO/O0 \\
$0.30 \mathrm{~m}(2)$ & $A A-10039226$ & sediments & $182 \pm 39$ & $131-283$ & -22.7 \\
$1.00 \mathrm{~m}(6)$ & $A A-10039321$ & sediments & $4,905 \pm 60$ & $5,466-5,740$ & -21.3 \\
$1.55 \mathrm{~m}(10)$ & $A A-10039417$ & sediments & $6,004 \pm 49$ & $6,670-6,929$ & -19.1 \\
$3.20 \mathrm{~m}(22)$ & $A A-1003955$ & sediments & $7,542 \pm 50$ & $8,195-8,396$ & -20.5 \\
\hline
\end{tabular}

(2) palynological samples, *Calibrated with CALIB 7.0 at $2 \sigma$ (Stuiver et al., 2005)

TABLE 3. Radiocarbon dating used in the work.

\begin{tabular}{|c|c|c|c|c|}
\hline Profile & Sample & ${ }^{14} C$ years $B P$ & Cal. years B.P* & References \\
\hline Estancia Thomas & Sediments & $182 \pm 39$ & $131-283$ & This paper \\
\hline QS1 Archaeological Site & $\begin{array}{l}\text { Lama guanicoe } \\
\text { (Müller, 1776) (bone) }\end{array}$ & $360 \pm 40$ & $305-474$ & Madrid et al. (2002) \\
\hline Lobería I & Mamal (bone) & $440 \pm 60$ & $320-526$ & Rabassa et al. (1989) \\
\hline QS1 Archaeological Site & Lama guanicoe (bone) & $790 \pm 40$ & $642-738$ & Madrid et al. (2002) \\
\hline QS1 Archaeological Site & Lama guanicoe (bone) & $940 \pm 40$ & $734-912$ & Madrid et al. (2002) \\
\hline QS1 Archaeological Site & Lama guanicoe (bone) & $960 \pm 40$ & $746-919$ & Madrid et al. (2002) \\
\hline La Toma & Vertebrate (bone) & $995 \pm 65$ & $735-960$ & Rabassa et al. (1989) \\
\hline Estancia Thomas & Sediments & $4,905 \pm 60$ & $5,466-5,740$ & This paper \\
\hline Sauce Grande & Sediments & $5,010 \pm 120$ & $5,465-5,949$ & Borromei (1992) \\
\hline Estancia Thomas & Sediments & $6,004 \pm 49$ & $6,670-6,929$ & This paper \\
\hline Sauce Chico & Sediments & $6,170 \pm 170$ & $6,638-7,417$ & Prieto (1989) \\
\hline Estancia Thomas & Tagelus plebeius (shells) & $7,720 \pm 100$ & $7,975-8,371$ & Farinati and Zavala (1995) \\
\hline Pehuen-Có & Sediments & $12,000 \pm 100$ & $13,560-14,065$ & $\begin{array}{c}\text { Aramayo and Manera de Bianco } \\
\text { (1996) }\end{array}$ \\
\hline Pehuen-Có & Vertebrate (bone) & $16,440 \pm 320$ & $18,995-20,535$ & Aramayo (1997) \\
\hline Castelar & Sediments & $20,180 \pm 180$ & $23,724-24,721$ & Grill and Morrás (2010) \\
\hline
\end{tabular}

${ }^{*}$ Calibrated with CALIB 7.0 at $2 \sigma$ (Stuiver et al., 2005)

\section{RESULTS AND DISCUSSION}

\section{Late Pleistocene}

The sediments corresponding to this age, (Estancia
Thomas Profile) (Agua Blanca Sequence, Middle Section) (Zavala and Quattrocchio, 2001), are composed of poorly sorted, yellowish to greyish fine sandstones (10YR6/2 to 5 

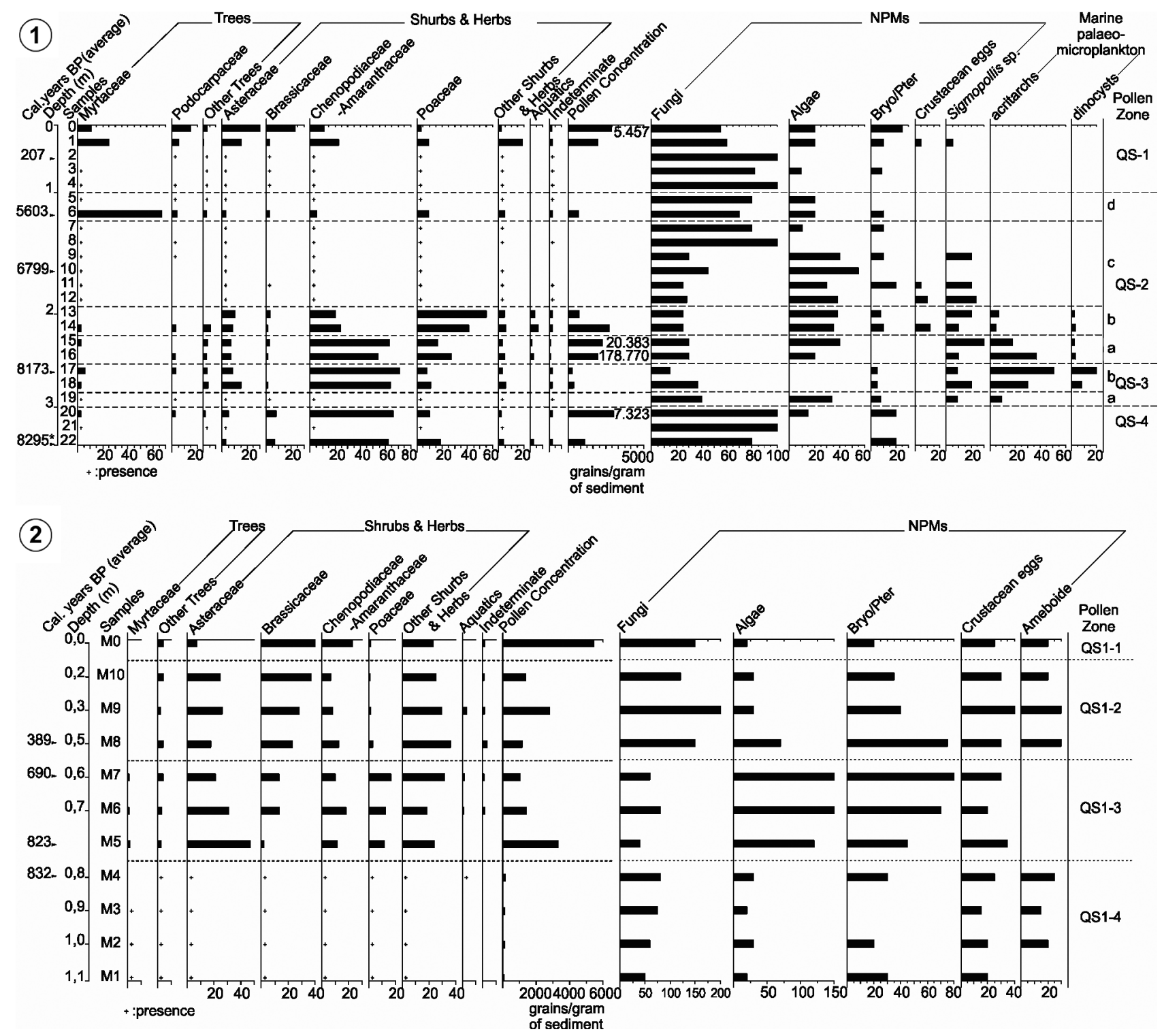

Figure 3. Non pollinic and pollinic frequency diagram of fossil samples: 1, Estancia Thomas Profile (modified from Grill, 2003). 2, QS 1 Archaelogical Site profile (modified from Grill et al., 2010).

GY6/1), 1.30 m thick, with considerable bioturbation due to radicular activity. The upper $20 \mathrm{~cm}$ contain a dark green bank of sandstones (5Y2/1) with more intense bioturbation. Due to the absence of primary sedimentary structures and according to regional data, these deposits are related to aeolian dynamics (Farinati and Zavala, 1995). Afterwards, during a more stable period, there is evidence of soil development, of which only part of its " $A$ " horizon was preserved.

At the bottom of the Agua Blanca Sequence, Middle
Section, the palynological samples turned out barren (Grill, 2003). Presumably, adverse factors such as chemical oxidation under arid conditions and an alkaline environment hindered the preservation of palynomorphs (Dimbleby, 1985). Horowitz (1992) suggests that extremely arid climates prevent the development of plant cover in the resulting landscape.

Barren pollen samples have been recorded in other Late Pleistocene profiles of the south of the Pampean Region, 

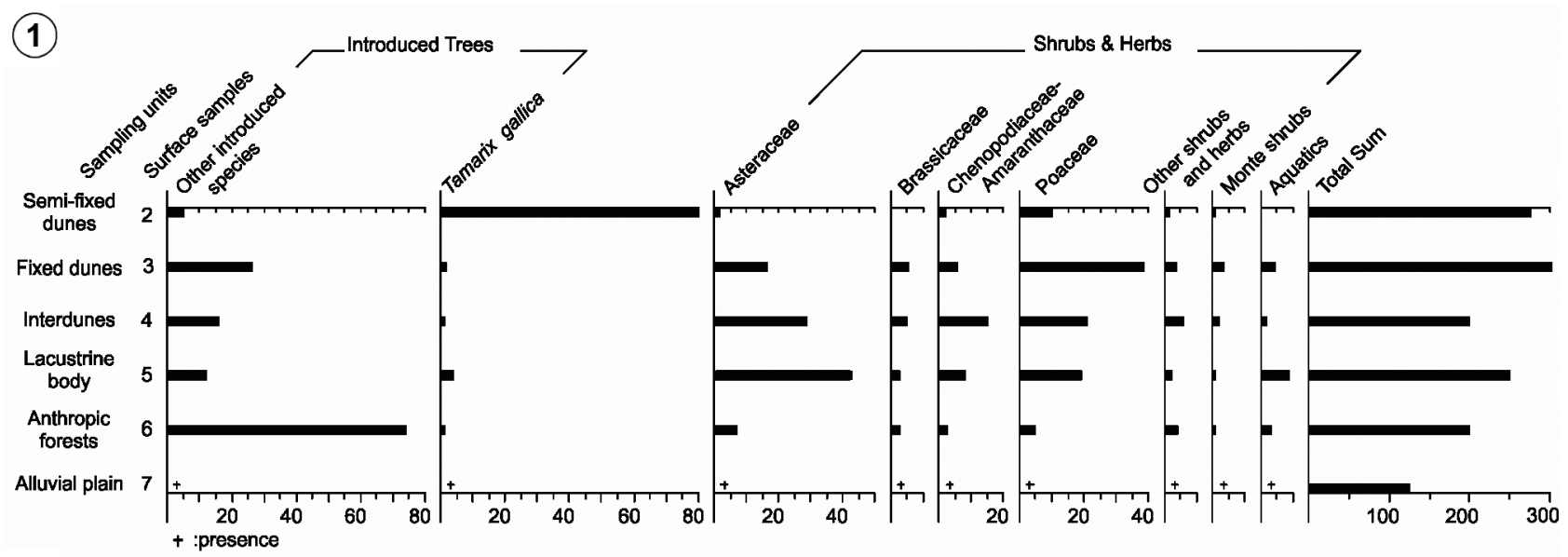

(2)

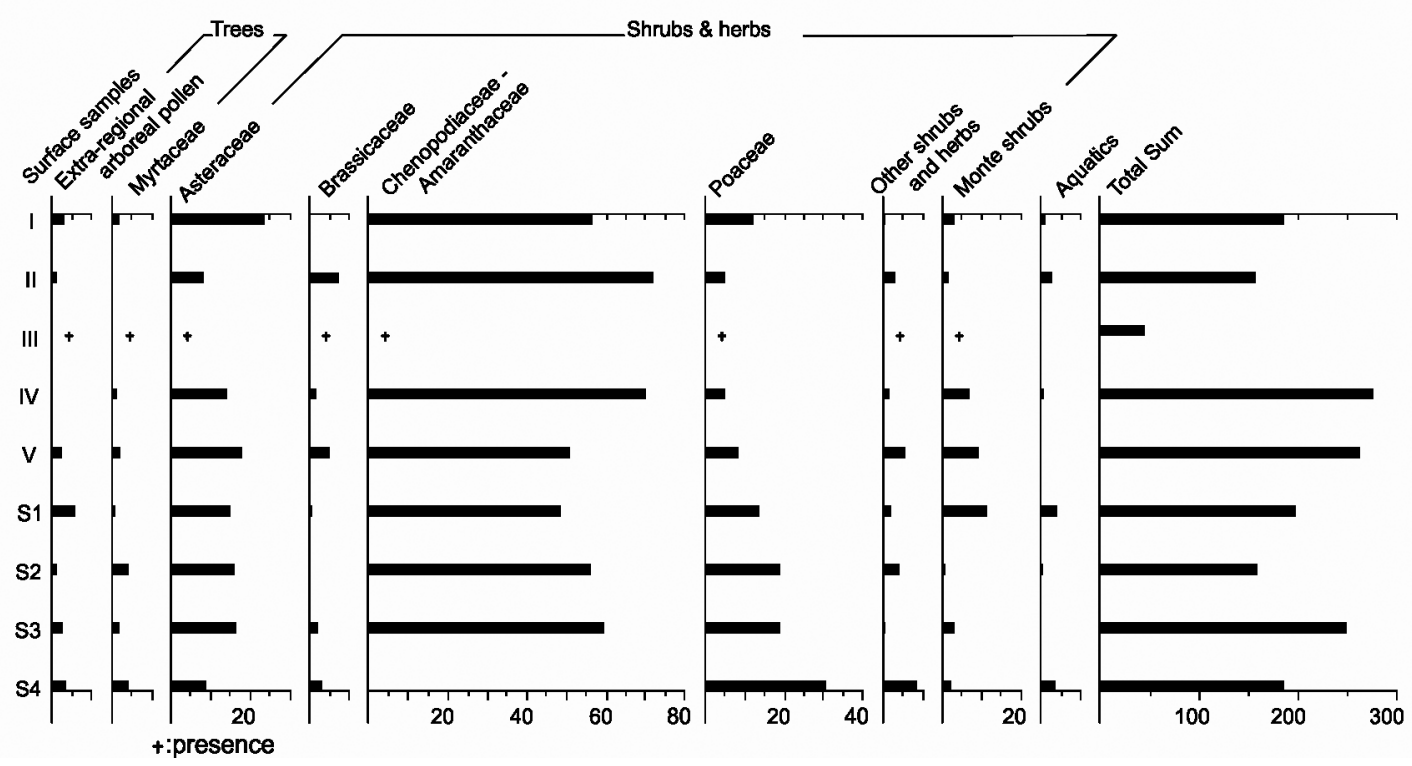

Figure 4. Pollen frequency diagram of surface samples: 1, Quequén Salado River (modified from Grill and Lamberto, 2006). 2, Estuary of Bahía Blanca (modified from Grill and Guerstein, 1995).

such as the Napostá Grande Stream (Grill, 1993, 1995) and the Quequén Grande River (Grill et al., 2007). Commonly, the remaining pollen assemblages from this age have predominantly been associated with the Brassicaceae family. The development of these weeds may imply environmental disturbance, caused by aridity and strong eolian activity, which may have also caused the retraction of grasslands (León and Anderson, 1983).

In accordance with the sedimentology and pollen analysis, Martínez and Gutiérrez Tellez (1998) recorded scarce ostracods and diatoms at Estancia Thomas Profile for this geological moment, thus inferring severe environmental conditions.

Such climate conditions could be related to a lower sea level than the inferred for the Pehuen-Có Palaeoicnological Site, in the coast of Buenos Aires Province $(100 \mathrm{~km}$ south of Quequén Salado), where alluvial plain sediments were dated in 13,812 cal. yr BP (Aramayo and Manera de Bianco, 1996), and a bone remain was dated in 19,765 cal. yr BP (Aramayo, 1997).

North of the Pampean Region (Undulated Pampa), studies of palynofacies associated with loess sediments 
suggested arid conditions for the Late Pleistocene (Grill and Morrás, 2010), although they indicate a slightly older episode $(24,222$ cal. yr BP) than that recorded for the Quequén Salado River. SE of Buenos Aires Province (near Mar del Plata), Zárate (1991) stated that, between LGM and 10,000 yr BP, there was an obliteration in the main valleys of the region as a consequence of aeolian activity.

Towards the top of this unit (Late Pleistocene/Holocene transition) and in connection with the recorded pedogenetic event, pollen spectrums dominated by Chenopodiaceae (64\%) were found (QS-4 Pollen Zone) (Grill, 2003), which are analogous to those obtained by Grill and Guerstein (1995) in pollen surface samples in Bahía Blanca Estuary. These spectrums evidence areas colonized by halophytic steppes (Verettoni, 1961). These types of plant communities are typical of coastal marine and continental environments with highly saline levels.

Considering the low pollen concentration, the scarce diversity of pollen and the exiguous palaeosoil associated, this part of the sequence can be interpreted as a brief episode of climatic stability indicating relative climate improvement.

The pedogenetic event recorded at the Estancia Thomas Profile might be correlated with the Puesto Callejón Viejo palaeosoil (Fidalgo et al., 1973), which covers a wide extension of the Pampean Region and appears frequently decapitated or is scarcely developed (Borromei, 1995, 1998; Grill, 1995, 1997; Quattrocchio et al., 2008, among others).

\section{Early Holocene}

During the Early Holocene, after an erosive unconformity, a rise in the sea level was evidenced in the area through the sedimentology and the content of gastropods and palynomorphs.

This part of the sequence is assigned to the Las Escobas Formation (Fidalgo et al. 1973). It is composed of $0.35 \mathrm{~m}$ of thick and thin bioclastic deposits, finning and thinning upwards, in which three marine sedimentary facies were recognized, "A", "B" and "C" (Farinati and Zavala 1995).

Facies type " $A$ " is a massive tabular body (2-4 cm thick) of well-sorted, yellowish orange middle-sized sandstones. It is interpreted as a transgressive residual deposit (Swift, 1968; Posamentier and Allen, 1993). Such deposit is associated with a progression of the coastline into the continent
(Farinati and Zavala, 1995). In this facies, QS-3a Pollen Subzone (Grill, 2003) is characterized by scarce pollen grains and evidences the destruction of littoral communities following a transgressive event, which is further evidenced by the presence of Micrhystridium sp. and Cymatiosphaerasp. acritarchs.

Facies type " $\mathrm{B}$ " is characterized by an irregular tabular body (10-20 cm thick), comprised of skeletal accumulations of mollusc shells Ostrea spreta (d`Orbigny, 1846), Brachidontes rodriguezi (d`Orbigny, 1846) and Tagelus plebeius (Lightfoot, 1786) with diffuse horizontal lamination and a matrix of medium-sized/very thick sand. This facies is interpreted as evidencing an accretion process in a foreshore environment (Heward, 1981; Farinati and Zavala, 1995).

Facies type " $C$ " consists of poorly selected fine/mediumsized sandstones comprising a $20 \mathrm{~cm}$ thick tabular body. It has dispersed gastropods and Tagelus plebeius valves in living position (Farinati and Zavala, 1995). Radiocarbon dating on the Tagelus plebeius valves yielded (8,173 cal. yr $\mathrm{BP})$. This facies is interpreted as the consequence of an accretion event in a mixed flat plain environment (Erikson et al., 1981; Farinati and Zavala, 1995).

The pollen spectrum of Facies " $\mathrm{B}$ " and " $\mathrm{C}$ " is mainly characterized by Chenopodiaceae (67.5\%) (QS-3b Pollen Zone) (Grill, 2003), while the marine palaeomicroplankton is characterized by the acritarchs Micrhystridium sp. (Deflandre, 1937), Cymatiosphaera polonica (Górka, 1974) and Cymatiosphaera sp. (Wetzel, 1933) and, to a lower extent, by Spiniferites (Mantel, 1985) dinoflagellate cysts.

All the recorded palynomorphs (pollen and marine palaeomicroplankton) are similar to those documented in the modern samples of Bahía Blanca Estuary (Grill and Guerstein, 1995). The genus Spiniferites has also been identified in modern neritic environments (Wall et al., 1977). In fossil samples, both the acritarchs and the dinoflagellate cysts suggest estuarine and neritic environments (Staplin et al., 1965; Sarjeant et al., 1987; among others).

The low diversity and proportion of marine microplankton, as compared to the total amount of palynomorphs, suggest unsuitable environments for the preservation of the specimens, considering the thick granulometry of the sediments, the moderate-high energy of the tidal action (Facies " $\mathrm{B}$ ") and the occasional storms (Facies " $\mathrm{C}$ ") (Farinati and 
Zavala, 1995). At the same time, the low diversity and proportion of cysts over the number of acritarchs illustrates restricted marine environments (Gibson et al., 1980).

The NPMs, Glomus sp. and Botryococcus sp., indicate relatively arid pulses. Glomus sp. is particularly indicative of erosive processes which are active in neighbouring areas (Medeanic et al., 2008), and Botryococcus sp. is typically associated with brackish-water oligotrophic environments, typical of littoral areas such as lagoons and intertidal marshes (Guy-Ohlson, 1992; van Gell and Aptroot, 2006; Medeanic et al., 2008). Pteridophyte spores indicate locally humid strata.

In the same profile at Estancia Thomas, Martínez and Gutiérrez Tellez (1998) recorded populations of ostracods and diatoms in which littoral marine species are dominant (the ostracods Cytherura dimorphica Bertels and Martínez, 1997, Leptocythere sp., Perissocytheridea sp. and Semixestoleberis debueni Hartmann, 1962, and the diatoms Actinoptychus splendens Shadbolt, 1854, Actinoptychus senarius Ehrenberg, 1843 and Triceratium sp. Ehrenberg, 1839). From Facies " $A$ " to " $C$ ", the relative frequencies and the diversity of marine species decrease, while limnic species increase.

The palynomorphs identified in Facies " $A$ ", " $B$ " and " $C$ " evidence the permanence of subhumid-dry conditions, developing in the area since the Pleistocene/Holocene transition. Some of the NPMs indicate brief arid pulses.

The transgressive event described herein ends at the Estancia Thomas area, with the settlement of a brackish lacustrine body. Since the transgression flooded the Pleistocene valley, the decreasing energy and the final restriction would respond to the evolution of a littoral barrier at the limits of the palaeovalley, thus interrupting the connection between the marine deposits and those recorded later (Farinati and Zavala, 1995).

\section{Middle Holocene}

The foresaid lacustrine sediments from the Upper Section of the Agua Blanca Sequence (Zavala and Quattrocchio, 2001) were deposited on top of an erosive unconformity. They are $2.20 \mathrm{~m}$ thick and comprise decreasing layers of sand and pelites, with Characeae oogonia and a large amount of shells of Heleobia australis (d'Orbigny, 1835), among others (Farinati and Zavala, 1995). The presence of this last estuarine species, with high phenotypic plasticity and an optimal habitat for mesohaline gradient (8-18\%), suggests a significant level of salinity, though insufficient to reach typical marine levels (Aguirre and Fucks, 2004).

In this part of the stratigraphic sequence, the palynomorphs and NPMs are considerably variable in diversity and concentration of the different taxa. As a consequence, QS-2 Pollen Zone has been subdivided into 4 Pollen Subzones (QS-2a, b, c, and d) (Grill, 2003).

The lower part (QS-2a and b Pollen Subzones) evidences a continuity of the halophyte communities developing in the area since the Pleistocene/Holocene transition (QS2a Pollen Subzone), replaced later by grass communities (Poaceae 48\%) (QS-2b Pollen Subzone), thus indicating relatively more humid conditions, similar to those currently characterizing the plains and wetlands at the eastern and southeastern Pampean Region (Prieto, 1996). The presence of scarce marine microplankton (Micrhystridium sp., Micrhystridium balmei Sarjeant, 1973 and Spiniferites sp.) indicates that, in its dropping to the current position, the sea invaded occasionally some areas of the basin.

Inland, in other fluvial systems close to the Quequén Salado, relatively more humid conditions were recorded. These were associated with hydrophytic communities related to lacustrine bodies (Sauce Chico stream) (7,027 cal. yr BP) (Prieto, 1989) and, in somewhat younger sediments, to the grass steppe (Sauce Grande River) (5,707 cal. yr BP) (Borromei, 1992).

The top of the sequence (1.60 m thick) shows a significant change in microfossil content. At QS-2c Pollen Subzone $(6,799$ cal. yr BP) only a few pollen taxa were recorded, indicating shallow brackish flooding surfaces. Among them, Corticiaceae, Glomus sp., Botryococcus sp., Spirogira sp. and Sigmopollis sp., 28 types of spores (van Geel et al., 1982/1983) and crustacean eggs (Fig. 5) stand out. Glomus sp. is a common microfossil identified among the NPMs of the southern Brazilian coast during arid periods of the Holocene regressive stages (Medeanic et al., 2008). Spirogira sp., Sigmopollis sp. and completely oxidized tracheid remains evidence fluctuations in the water level. The environmental characteristics presumably unfavoured the preservation of the pollen grains in this part of the sequence.

The predominance of Lymnocythere sp. (94\%) and the 
presence of the Surirella striatula (Turpin, 1828) and Campylodiscus clypeus (Ehrenberg ex. Kützing, 1844) (QS-2b Pollen Subzone and part of QS-2c Pollen Subzone) suggest the development of an oligo-mesohaline brackish littoral lagoon (Martínez and Gutiérrez Tellez, 1998). For the rest of QS-2c Pollen Subzone, the alternance of planktonic diatoms (Hyalodiscus laevis Ehrenberg, 1845) and benthic diatoms (Surirella striatula) evidences variable precipitations and ongoing water level fluctuations in the developing water bodies.

This Pollen Zone ends with QS-2d Pollen Subzone (5,603 cal. yr BP), dominated by Myrtaceae (50\%). The dominance of this taxon over the typical herbaceous-shrubby components of the steppe and the low pollen concentrations suggest an increase in the sedimentation rates due to intense erosive processes (QS-2c Pollen Subzone), which apparently intensified during this stage. The Myrtaceae family, with characteristics extra-regional for the Pampean Region, indicates the persistence of considerably intense air masses, probably from the woodlands of southern Brazil and northern Argentina.

Pollen spectrums with high proportions of Myrtaceae belonging to the Middle/Late Holocene have been recorded in other alluvial basins of southern Buenos Aires (Grill, 1993; Fernández, 2012).

As regards eustatic fluctuations during the Early/Middle Holocene, plentiful evidence suggests that this event spread throughout the Atlantic coast, affecting not only the Buenos Aires littoral area (Grill and Quattrocchio, 1996; Fontana, 2005; Olivera et al., 2006; Vilanova et al., 2006, among others) but also southern Brazil (Grill and Medeanic, 2004; Medeanic and Correa, 2007, among others).

\section{Late Holocene-historical times}

The last 1,000 yr BP, very well represented in the QS Archaeological Site, are comprised by alluvial sediments from the Quequén Salado flood plain (Farinati and Zavala, 1995). These sediments are assigned to the Chacra La Blanqueada Formation (Rabassa, 1989; Zavala and Quattrocchio, 2001).

The $1.10 \mathrm{~m}$ thick sequence starts with $30 \mathrm{~cm}$ of darkbrown clayey silt which yielded 832 cal. yr BP towards the top. In $\mathrm{QS}_{1}$-4 Pollen Zone, only the presence of pollen grains, abundant fungal spores (Corticiaceae Microthyriaceae,
Monosporites sp., Dicellaesporites sp., Pluricellaesporites sp., Dictyosporites sp., and Glomus sp.) among others, and, to a lower extent, algae spores (type 181 and 128 A/B) (van Geel et al., 1982/1983) and Bryophyte (Anthoceros sp., Phaeoceros sp., Riccia sp.) were recorded (Grill et al., 2010).

In the palynofacies study of modern sediments from the Quequén Salado flood plain (sample 7), palynomorphs were characterized by a scarce proportion of pollen grains, similarly to $\mathrm{QS}_{1}-4$ Pollen Zone, evidencing a considerable damage due to mechanical influence, and chemical and biological oxidation (Grill and Lamberto, 2006).

Pollen assemblages from archaeological sites which are seasonally flooded become more easily altered or barren than those belonging to constantly dry or humid sites (Bryant and Holloway, 1983). This condition is related to the mechanical damage undergone by pollen grains as a consequence of the alternating humidity and drought periods, which, in turn, enables biological activity (by bacteria and fungus) and, in time, leads to pollen destruction.

Regarding the NPMs recorded in this Pollen Zone, the higher proportion and diversity of fungal spores in relation to algae spores indicates that the exposure periods were longer than the flooding periods, the first being more resistant to droughts than the latter (Medeanic and Silva, 2010). In addition, Bryophyte Riccia sp, Phaeoceros sp and Anthoceros sp. spores ratify the locally humid environments in the proximities to the runoff, and the last two have also been currently related to cultivated fields (Hässel de Menéndez, 1962, 1979). For the moment, this hypothesis is disregarded for the analysis, as there is no concrete evidence of agricultural development in the region (Grill et al., 2010).

In relation to the conditions of periodic humidity, these are assumed to have influenced the criteria for human settlement at the river neighbouring area. There is evidence to posit that, in dry periods, flooding plains were the environment preferred for human settlement. Due to the proximity to the river and considering the regional arid conditions, this choice was favourable during large-mammals hunting seasons, which is corroborated at QS 1 Site by the significant proportion of archaeological remains found in the sediments (Grill et al., 2010).

In concordance with the results obtained for the Que- 
quén Salado lower basin, periods with important aeolian activity were recorded NE and $\mathrm{S}$ of the Pampean grasslands. These were associated with numerous short, dry episodes during the Late Holocene (Zárate et al., 2000; Muhs and Zárate, 2001).

QS $_{1}$-3 Pollen Zone (823-690 cal. yr BP) (Grill et al., 2010), involving $10 \mathrm{~cm}$ of sandy siltstone, presents a pollen assemblage similar to the surface pollen samples from the current fixed dunes and interdunes at the Quequén Salado lower basin (Grill and Lamberto, 2006) (samples 3 and 4, Fig. 4). However, it has a higher proportion of Brassiaceae. These communities reflect the development of a psammophyte herbaceous steppe (Verettoni, 1965; Verettoni and Aramayo, 1976). In this Pollen Zone, the highest proportion of Poaceae in the profile was recorded, along with the broadest diversity of pollen from the "shrubby forest". Accordingly, a high proportion of NPMs was found, with algae spores (Zygnema sp., and others) and Bryophyte (Phaceros sp., Anthoceros sp.) outnumbering fungal spores.

This Pollen Zone is also characterized by having the highest number of vertebrate remains, mainly mammals, in the sequence (e.g. even-toed ungulates, mostly Lama guanicoe Müller, 1776), with sediments marked by a strong anthropic activity (Grill et al., 2010). Among the vertebrates were Brazilian elements like the rodent Cavia aperea (Erxleben, 1777).

A relative improvement in the climatic conditions is inferred for this geological moment on the basis of the pollen assemblage, the NPMs (the higher proportion of algae spores over fungal spores) and the fossil vertebrates.

At La Toma Archaeological Site (about $180 \mathrm{~km}$ from the study area), the vertebrates (847 cal. yr BP) were also of Brazilian lineage indicating warmer climate (Dasypus Linneo, 1758 and Cavia aperea) (Rabassa et al., 1989).

Accordingly, in sediments dated in 1,000-500 yr BP at El Tigre Archaeological Site (approximately $300 \mathrm{~km}$ south $\mathrm{QS}_{1}$ ), the NPMs also record a significant proportion of zygnematales (Spirogira sp. and Mougeotia sp.) (Fernández, 2012), along with the presence of the sigmodontine rodent Holochilus brasiliensis (Desmarest, 1819) (Stoessel et al., 2008).

These data from the $\mathrm{QS}_{1}$, La Toma and El Tigre sites suggest an improvement of the regional climate, coetaneous to the global Medieval Climatic Optimum (Rabassa et al., 1989).

From $389 \mathrm{cal}$. yr BP to present time, the last $70 \mathrm{~cm}$ of the $\mathrm{QS}_{1}$ Site profile involve the presence of dense and compact siltstone ending in the modern soil. The pollen spectrums (QS 1 -2 and QS ${ }_{1}-1$ Pollen Zones) (Grill et al., 2010) are dominated by the family Brassicaceae (average of $43 \%$ ), with an abrupt decrease of the family Poaceae $(<2 \%)$ and aquatic plants $(<1 \%)$.

In the pollen spectrums of modern samples from the Quequén Salado River, the family Brassicaceae reaches a maximum representation of $4 \%$ (Grill and Lamberto, 2006), as in other superficial samples from the Pampean Region (wet and dry Pampa), where the values oscillate between 6 and 9\%, respectively (Prieto, 2000). However, it reaches $26 \%$ at the xerophitic woodland-grassland ecotone, thus suggesting that semi-arid climates are necessary for the development of these weeds (Prieto, 2000). In the same way, in disturbed environments or in dunes dominated by Cakile maritima (Scopoli, 1772), the values oscillate between 59\% and 45\% (Stutz, 1996; Fernández, 2012).

Approximately $300 \mathrm{~km}$ south of $\mathrm{QS}_{1}$ Site, at the Loma Ruiz archaeological Site, pollen spectrums (last 2,000 yr BP) showed resemblance to those from $\mathrm{QS}_{1}$, although Loma Ruiz presented higher proportions of Brassicaceae $(70 \%$ on average). In these environments, associated with dunes and herbaceous psammophytic grassland, the predominance of Brassicaceae was interpreted as evidence of the environmental disturbance of the site caused by the repeated departures of the inhabitants (Fernández, 2012).

At the Lobería I Archaeological Site, approximately 170 $\mathrm{km}$ from the study area, the mammal fauna (dated in 423 cal. yr BP) indicated a climatic deterioration correlatable to the Little Ice Age (Rabassa et al., 1989).

Further evidence of the Little Ice Age in the Pampean Region, obtained through the study of mammals, suggests dry and arid conditions around 449 years BP (Tonni et al., 1999), with a more benign pulse around 300 years BP (Pardiñas and Tonni, 2000), which indicates that there were climatic variations on the secular scale in this region. Based on historical data, Moncaut (2001) analysed floodings and droughts during the 1,576-2,001 lapse, stating that the droughts were particularly strong during the Little Ice Age. Laprida and Valero Garcés (2009) identified a marked salini- 

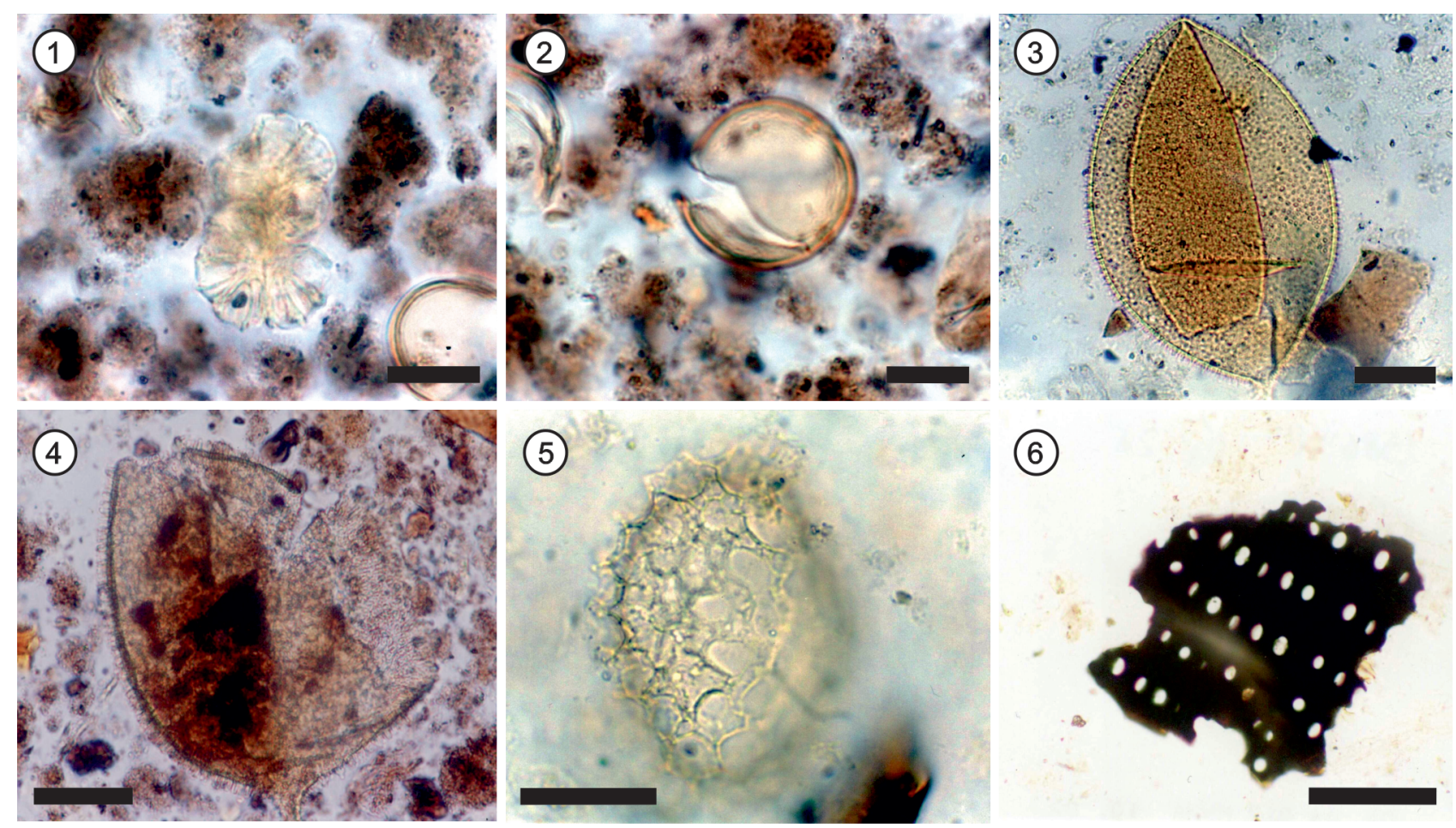

(6)

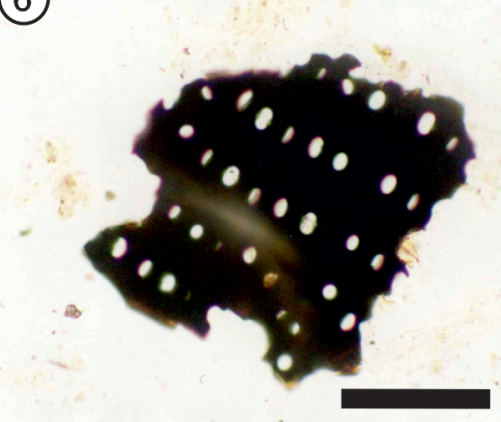

Figure 5. NPMs remains found in QS-2c Pollinic Subzone (Estancia Thomas profile). 1, Botryococcus sp. 2, Sigmopollis sp. 3 and 4, Copepods eggs. 5, Rotifers eggs. 6, Tracheid. Scale bar $=50 \mu \mathrm{m}$, except 1, 2 and 6 scale bar $=20 \mu \mathrm{m}$.

zation in the Chascomús lagoon, from the beginning of the $18^{\text {th }}$ century to the middle of the $19^{\text {th }}$ century, based on evidence yielded by sedimentology, geochemistry and ostracods.

In the Estancia Thomas area, the stratigraphic sequence ends with $70 \mathrm{~cm}$ thick light gray sandy sediments, with net-erosive base on the preceding unit. This unit is interpreted as deposited by overflows at the modern mouth of the Quequén Salado River and is assigned to Chacra La Blanqueada Formation (Rabassa, 1989). In these sediments, at least one former palaeosurface was found, characterized by the presence of an edaphization level (Farinati and Zavala, 1995). The sequence ends with the present soil. Radiocarbon dating on the organic matter of the sediments at the top of this unit yielded a minimum age of $207 \mathrm{cal}$. yr BP.

QS-1 Pollen Zone (Grill, 2003), recorded in this unit, starts with three samples yielding only a presence of pollen grains, not enough to reconstruct the plant communities. The NPMs are represented by fungal spores types " $\mathrm{B}$ " and "J" (Romero and Fernández, 1981), Pluricellaesporites sp. and Glomus sp., among others, and by Botryococcus sp. and algae type 128 A/B (van Geel et al., 1982/1983). Among these, Glomus sp. indicates active erosive processes, and Botryococcus sp. evidences arid conditions and oligotrophic environments (Guy-Ohlson, 1992; van Gell and Aptroot, 2006).

Towards the top of the unit (207 cal. yr BP), the two samples closest to the surface present an assemblage analogous to the one currently colonizing the dunes and interdunes depressions at the lower basin of the Quequén Salado (Grill and Lamberto, 2006), but with lower proportions of Poaceae. The anthropic influence of the natural plant communities is evidenced by Tamaricaceae, Brassicaceae (7\%), Eucalyptus sp. and Pinus sp. Among the NPMs, Bryophytes (Phaceros laevi Proskauer, 1951) and Pteridophytes spores stand out, along with some fungal spores (Glomus sp.).

The human impact evidenced in the assemblages is similar to that recorded in other equivalent stratigraphic sequences from rivers and streams of the region (Borromei, 
TABLE 4. Synthesis of the palaeoenvironmental and palaeoclimatic fluctuations registered at the lower basin of the Quequén Salado River, from multi-proxies analysis.

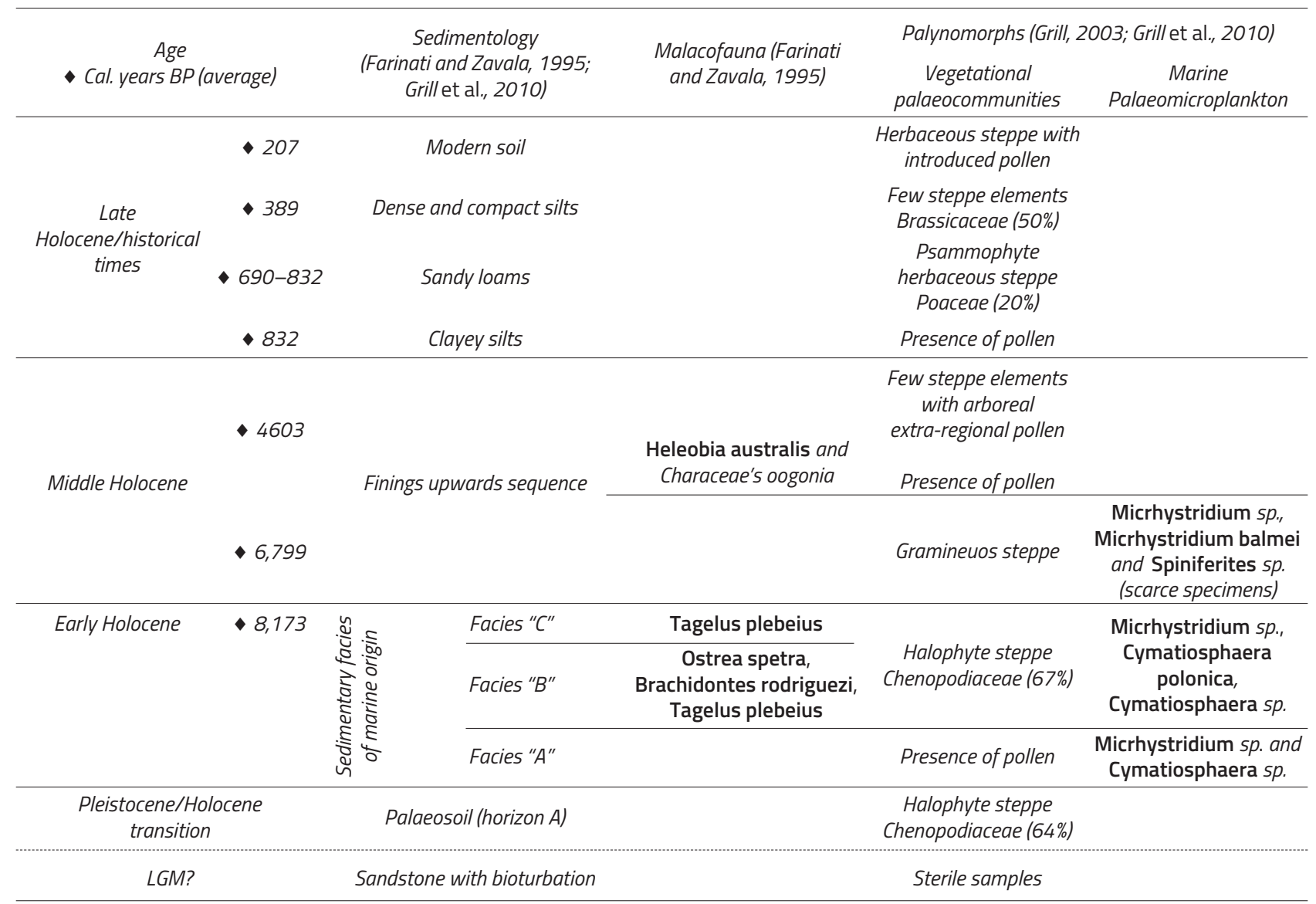

1995, 1998; Grill, 1995, 1997, among others).

The palaeoclimatic inferences for the base of the upper section of the Estancia Thomas Profile indicate adverse conditions for pollen preservation but favourable for the development of the previously mentioned NPMs (Glomus sp. and Botryococcus sp.). Such conditions might correlate to those inferred for the QS 1 Site (Little Ice Age?). Towards the top of the Estancia Thomas Profile, an establishment of subhumid/dry conditions, reminiscent of today climate, is inferred by the palynomorph assemblages.

\section{CONCLUSIONS}

The steppe communities recorded from the Late Pleistocene (LMG?) to present time confirm, as stated by Barreda et al. (2007), that the Argentinian flora of the studied geological lapse does not differ significantly from the modern flora. The variations observed in the proportions of the different pollen types and in the composition of the assemblages would be related to the movement of the Atlantic and Pacific anticyclones, to the variations of the west and east winds, and to sea level fluctuations.

For the Late Pleistocene (LGM?), when the sea level was lower than today, barren palynological samples illustrate adverse conditions for pollen preservation. These were associated with environments of extreme aeolian and arid conditions. The scarce populations of ostracods and diatoms ratified such inferences.

During the Late Pleistocene/Holocene transition, a brief episode of climatic stability, associated with a pedogenetic event, was inferred for the Estancia Thomas Profile sequence. The halophyte communities were similar to those currently colonizing the mudflats of Bahía Blanca Estuary (200 km south the study area). This type of vegetal cover remained in the area approximately until the Middle 
TABLE 4. Continuation.

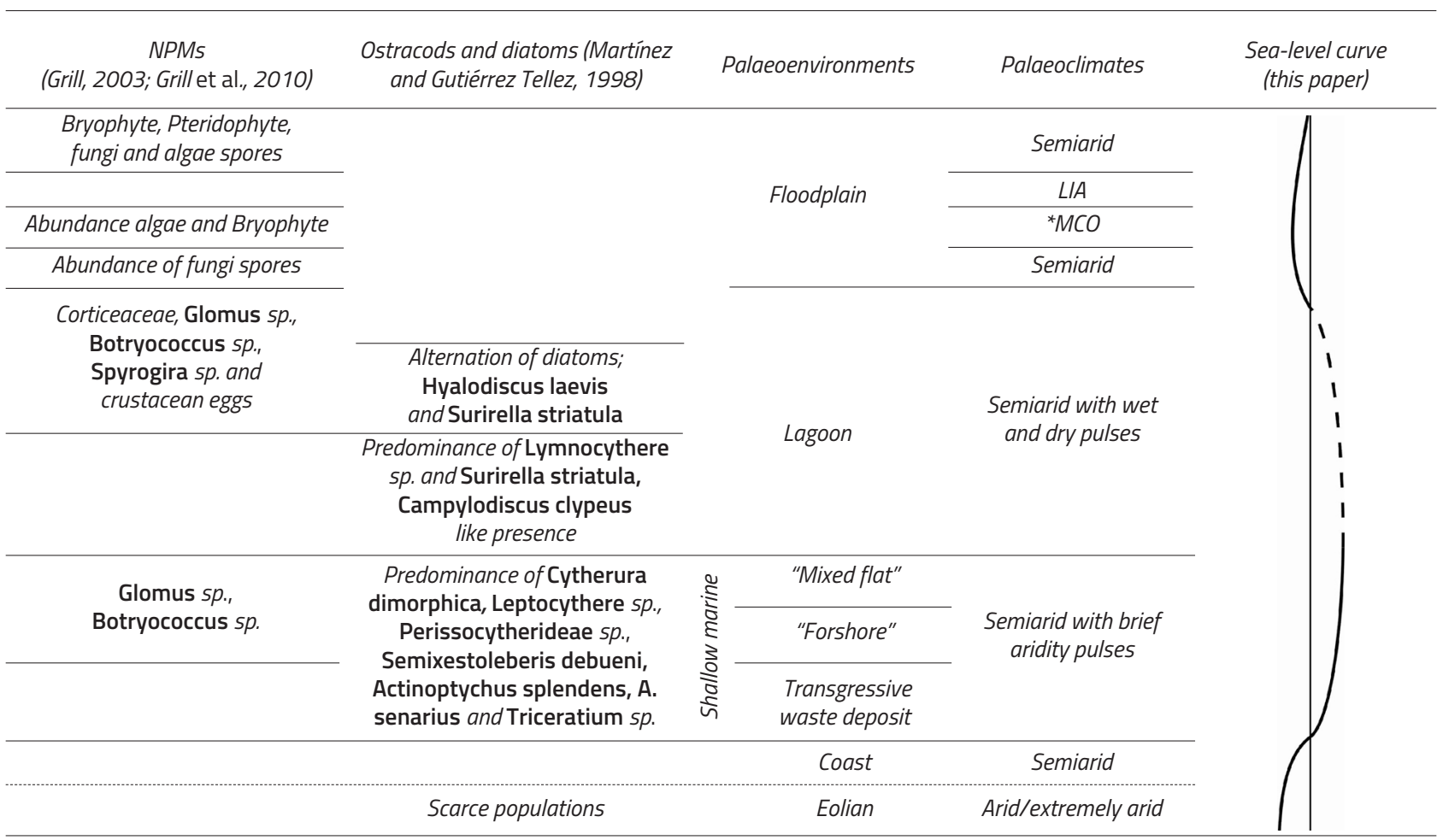

${ }^{*}$ Abundance of archeological and faunistic remains, Cavia aparea (Grill et al., 2010).

Holocene. For this area, the sedimentology, malacofauna and microfossils (acritarchs, marine palaeomicroplankton, ostracods and diatoms) evidenced a sea level rise during the Early Holocene (8,173 cal. yr B.P.). Some NPMs indicated brief arid pulses in a regional context of semiarid conditions. This transgressive event ended with the establishment of a brackish lacustrine body towards the Middle Holocene. Between 6,799 cal. yr BP and 5,603 cal. yr BP, the pollen assemblages, NPMs, ostracods and diatoms showed significant variability, thus evidencing an alternation between humid and dry pulses.

During the Late Holocene, 1.000 yr. BP, it can be posited that the lower basin of the Quequén Salado saw the settlement of modern ecosystems (dunes and interdunes), with the sea and the river resembling their current position.

At the $\mathrm{QS}_{1}$ Archaeological Site, two global climatic changes, the Medieval Climatic Optimum (823-690 cal. yr BP) and the Little Ice Age (389 cal. yr BP), were inferred on the basis of pollen and faunistic remains.

\section{ACKNOWLEDGMENTS}

We would like to express our thanks to the Department of Geology (U.N.S.) and to INGEOSUR, where the research was conducted. We thank the NSF-Arizona AMS Laboratory for their collaboration in the datings. This work was funded by grants of S.G.C.y.T. (24/H124) from the U.N.S. We further thank Juliana Cornago for her linguistic assistance in the translation of the article.

\section{REFERENCES}

Alberdi, M., Leone, G., and Tonni, E.P. 1995. Evolución Biológica y Climática de la Región Pampeana durante los últimos cinco millones de años. Un ensayo de correlación con el Mediterráneo Occidental. Monografías del Museo Nacional de Ciencias Naturales (Madrid), 12, CS1C: 145-161.

Alley, R. 1990. West Antartic Colapse - How likely? Episodes 13: 231-238.

Aramayo, S.A. 1997. Cronología radiocarbónica de localidades fosilíferas pleistocenas y holocenas de la costa Sud-Sudeste de la Provincia de Buenos Aires, Argentina. $6^{\circ}$ Congresso da associação brasilera do quaternário e reunião latinoamericana do quaternário (Curitiba), Resumos Expandidos: 305-308.

Aramayo, S.A., and Manera de Bianco, T. 1996. Edad y nuevos hallazgos de icnitas de mamíferos y aves en el yacimiento paleoicnológico de Pehuen Có (Pleistoceno tardío), provincia de Buenos Aires, Argentina. Publicación Especial de la Asociación Paleontológica Argentina 4: 47-57.

Aguirre, M.L., and Fucks, E. 2004. Moluscos y Arqueología de am- 
bientes del Cuaternario Marino en el sur de Entre Ríos y Litoral Bonaerense. In: F.G. Aceñolaza (Ed.), Temas de la Biodiversidad del litoral fluvial argentino, Instituto Superior de Correlación Geológica. Miscelánea 12: 55-70.

Barreda, V., Anzótegui, M., Prieto, A., Aceñolaza, P., Bianchi, M., Borromei, A.M., Brea, M., Caccavari, M., Garralla, S., Grill, S., Guerstein, G.R., Lutz, A., Mancini, M., Mautino, L., Ottone, G., Quattrocchio, M., Romero, E., Zamaloa, M.C., and Zucol, A. 2007. Diversificación y cambios de las angiospermas durante el Neógeno en Argentina. In: S. Archangelsky, T. Sánchez, and E.P. Tonni (Eds.), Publicación Especial de la Asociación Paleontológica Argentina, 11: 173-191.

Bayón, C., Martínez, G., Armentano, G., and Scabuzzo, C. 2004. Arqueología del valle inferior del río Colorado: el sitio La Primavera. Intersecciones en Antropología 5: 39-53.

Borromei, A.M. 1992. [Geología y Palinología de los depósitos Cuaternarios en el valle del río Sauce Grande, provincia de Buenos Aires, Argentina. Tesis Doctoral, Universidad Nacional del Sur, Bahía Blanca, 200 p. Inédita.].

Borromei, A.M. 1995. Palinología, estratigrafía y paleoambientes del Pleistoceno Tardío-Holoceno en el valle del río Sauce Grande, provincia de Buenos Aires, Argentina. Polen 7: 19-31.

Borromei, A.M. 1998. Vegetación y clima del Cuaternario tardío en el valle superior del Río Sauce Grande, Provincia de Buenos Aires. Argentina. Polen 9: 5-15.

Bryant, V.M., and Holloway, R.G. 1983. The role of palynology in archaeology. In: M. Schiffer (Ed.), Advances in Archaelogical Method and Theory 6. New York Academic Press, New York, p. 191-224.

Burgos, J. 1968. El clima en la provincia de Buenos Aires en relación con la vegetación y el suelo. In: A.L. Cabrera (Ed.), Flora de la provincia de Buenos Aires. Colección Científica. INTA, Buenos Aires, Parte 1, p. 101-123.

Cabrera, A. 1976. Regiones Fitogeográficas Argentinas. In: F.W. Kugler (Ed.), Enciclopedia Argentina de Agronomía y Jardinería, Tomo 2, Fascículo 1. Editorial ACME, Buenos Aires, p. 1-85.

Dimbleby, G. 1985. The palynology of archaeological sites. New Phytology 56: 12-28.

Erikson, K.A., Turner, B.R., and Vos, R.G. 1981. Evidence of tidal process from the lower part of the Witwatersrand Supergroup, South Africa. Sedimentary Geology 29: 309-325.

Farinati, E., and Zavala, C.A. 1995. Análisis tafonómico de moluscos y análisis de facies en la Serie Holocena del río Quequén Salado, provincia de Buenos Aires, Argentina. $4^{\circ}$ Congreso Argentino de Paleontología y Bioestratigrafía (Trelew), Actas: 117-122.

Fernández, A.L. 2012. [Palinología del Cuaternario tardío en la cuenca inferior del río Colorado, provincia de Buenos Aires, Argentina. Tesis Doctoral, Universidad Nacional del Sur, Bahía Blanca, 300 p. Inédita.].

Fidalgo, F., De Francesco, F.O., and Colado, U.R. 1973. Geología superficial de las hojas Castelli, J. M. Cobo y Monasterio (Provincia de Buenos Aires). $5^{\circ}$ Congreso Geológico Argentino (Córdoba), Actas: 27-39.

Fontana, S.L. 2005. Holocene vegetational history and paleoenvironmental conditions on the temperate Atlantic coast, as inferred from multi-proxy lacustrine records. Journal of Paleolimnology 34: 445-469.

Frengüelli, J. 1928. Observaciones geológicas en la región costanera sur de la provincia de Buenos Aires. Anales Facultad de Ciencias de la Educación (Paraná) 2: 1-145.

Frengüelli, J. 1950. Rasgos generales de la morfología y la geología de la provincia de Buenos Aires. Ministerio de Obras Públicas de la Provincia de Buenos Aires, Publicación del Laboratorio de
Ensayo de Materiales e Investigaciones Tecnológicas, Serie 2, 33: $1-72$.

Gibson, T.G., Edwards, L.E., and Frederiksen, N.O. 1980. Biological interpretation of depositional environment in lower Paleogene strata. In: R.W. Frey (Ed.), Excursions in Southeastern geology, V. II, Geological Society of America and American Geological Institute Guidebook, Field Trips 20, Atlanta, p. 428-431.

González Uriarte, M. 1984. Características geomorfológicas de la porción continental que rodea la Bahía Blanca, Provincia de Buenos Aires. $9^{\circ}$ Congreso Argentino de Geología (Bariloche), Actas 3: 556-576.

Grill, S.C. 1993. [Estratigrafía y paleoambientes del Cuaternario en base a palinomorfos, en la cuenca del arroyo Napostá Grande, provincia de Buenos Aires. Tesis Doctoral, Universidad Nacional del Sur, Bahía Blanca, 145 p. Inédita.].

Grill, S.C. 1995. Análisis palinológico de un perfil Cuaternario en la cuenca del arroyo Napostá Grande, localidad: García del Río, provincia de Buenos Aires. $6^{\circ}$ Jornadas Geológicas Bonaerenses (Junín), Actas 1: 99-107.

Grill, S.C. 1997. Palinología de un perfil cuaternario en el valle del arroyo Napostá Grande, provincia de Buenos Aires. Argentina. Polen 8: 25-42.

Grill, S.C. 2003. Análisis palinológico de sedimentos cuaternarios en la cuenca inferior del río Quequén Salado, provincia de Buenos Aires, Argentina. Polen 12: 37-52.

Grill, S.C., and Guerstein, G.R. 1995. Estudio palinológico de sedimentos superficiales en el estuario de Bahía Blanca, Buenos Aires (Argentina). Polen 7: 40-49.

Grill, S., Borromei, A., Martínez, G., Gutiérrez, M., Cornou, M., and Olivera, D. 2007. Palynofacial analysis in alkaline soils and paleoenvironmental implications: the Paso Otero 5 archaeological site (Necochea District, Buenos Aires province, Argentina). Journal of South American Earth Sciences 24: 34-47.

Grill, S.C., and Lamberto, S.A. 2006. Análisis palinofacial de sedimentos actuales en la cuenca inferior del río Quequén Salado, provincia de Buenos Aires, Argentina. (Primeros resultados). Revista Española de Micropaleontología 38: 77-92.

Grill, S., March, R., and Rodríguez Loredo, C. 2010. Sitio Arqueológico QS 1 (provincia de Buenos Aires, Argentina): Evidencias palinológicas de fluctuaciones paleoclimáticas durante los últimos 1000 años A.P. Comechingonia 13: 59-76.

Grill, S.C., and Medeanic, S. 2004. The palynomorph records from Holocene sediments in the southern coast of Buenos Aires province (Argentina) and Rio Grande do Sul State (Brazil). Palaeoenvironmental and Palaeoclimatic reconstructions. $6^{\circ}$ Reunión de Paleobotánicos e Palinólogos (Gramado, Brasil), Boletim do Resumos: 69.

Grill, S.C., and Morrás, H.J.M. 2010. Análisis palinofacial de sedimentos del Cenozoico tardío en la Pampa Ondulada, primeros resultados. Revista Brasilera de Paleontología 13: 221-232.

Grill, S.C., and Quattrocchio, M.E. 1996. Fluctuaciones eustáticas durante el Holoceno a partir del análisis de palinomorfos. Localidad: Grümbein, sur de la provincia de Buenos Aires. Ameghiniana 33: 435-442.

Gutiérrez, M., and Martínez, G. 2008. Trends in the faunal human exploitation during the Late Pleistocene and Early Holocene in the Pampean region (Argentina). Quaternary International 191: 53-68.

Guy-Ohlson, D. 1992. Botryococcus as an aid in the interpretation of paleoenvironment and depositional processes. Review of Palaeobotany and Palynology 71: 1-15.

Hässel de Menéndez, G.G. 1962. Estudio de las Anthoceratales y 
Marchantiales de la Argentina. Opera Lilloana 7: 1-297

Hässel de Menéndez, G.G. 1979. Riella pampae Hässel n.sp. (Hepaticae) la tercera especie del género hallado en Sudamérica. Revista Museo Argentino Ciencias Naturales, Sección Botánica, 5: 205-212.

Heward, A.P.1981. A review of wave-dominated clastic shoreline deposits. Earth Science Review 17: 223-276.

Horowitz, A. 1992. Palynology of arid lands. Elsevier Science Publishers B.V., Amsterdam, $546 \mathrm{p}$.

Kraglievich, J.L. 1960. Un nuevo roedor octodóntido del Eocuaternario de Salinas Chicas (Provincia de Buenos Aires). Revista de la Asociación Geológica Argentina 15: 15-40.

Laprida, C., and Valero Garcés, B. 2009. Cambios ambientales de épocas históricas en la pampa bonaerense en base a ostrácodos: historia hidrológica de la laguna de Chascomús. Ameghiniana 46: 95-111.

Leon, R.J.C., and Anderson, D.L. 1983. El límite occidental del pastizal pampeano. Tuexenia 3: 67-82

Madrid, P., Politis, G., March, R., and Bonomo, M. 2002. Arqueología microrregional en el sudeste de la Región Pampeana Argentina: el curso del río Quequén Salado. Relaciones de la Sociedad Argentina de Antropología 27: 327-355.

March, R., Joly, D., Rodriguez Loredo C., Thibault, C., and Grill. S. 2003. Rapport d'activités de la Mission archéologique Française en province de Buenos Aires du Ministères des Affaires Etrangères. Ministère des Affaires Etrangères Français, 132 p.

Marini, M.F. 2002. [Hidrografía del río Quequén Salado. Tesis Doctoral Universidad Nacional del Sur, Bahía Blanca, 162 p. Inédita.].

Martínez, D., and Gutiérrez Tellez, B. 1998. Asociación de Ostrácodos y Diatomeas del Cuaternario de un ambiente transicional del río Quequén Salado, provincia de Buenos Aires, Argentina. $7^{\circ}$ Congreso Argentino de Paleontología y Bioestratigrafía (Bahía Blanca), Actas: 36

Martínez, G., Armentano, G., Stoessel, L., Martínez, G.A., Alcaraz, A.P., González, N., and Santos, F. 2009b. Resultados Preliminares de la localidad arqueológica San Antonio (curso inferior del río Colorado, Pdo. de Villarino, pcia. de Buenos Aires). In: M. Berón, L. Luna, M. Bonomo, C. Montalvo, C. Aranda, and M. Carrera Aizpitarte (Eds.), Mamul Mapú: pasado y presente desde la arqueología pampeana. Libros del Espinillo, Ayacucho, p. 85-98.

Martínez, G., Stoessel, L., and Armentano, G. 2009c. Cronología, procesos de formación y ocupaciones humanas en el sitio El Tigre (curso inferior del río Colorado, Pdo.de Patagones, pcia. de Buenos Aires). Relaciones de la Sociedad Argentina de Antropología 34: 177-199.

Martínez, G., Zangrando, F.A.J., and Prates, L. 2009a. Isotopic ecology and human paleodiets in the lower basin of the Colorado River (Buenos Aires province, Argentina). International Journal of Osteoarchaeology 19: 281-296.

Medeanic, S., and Correa, I.C.S. 2007. Silicoflagellate Dictyocha Ehrenberg from the Middle Holocene sediments in the coastal plain of Rio Grande do Sul, Brazil. Revista Española de Micropaleontolología 39: 227-239.

Medeanic, S., Lima, L.G., and Correa, I.C.S. 2008. Non pollen palynomorphs (NPPs) from the Holocene sediments in the coastal plains of southern Brazil. $3^{\circ}$ International Workshop on Quaternary NPPs, Padova, Italy, 42-46.

Medeanic, S., and Silva, M.B. 2010. Indicative value of non-pollen palynomorphs (NPPs) and palynofacies for palaeoreconstructions: Holocene peats, Brazil. International Journal of Coal Geology 84: 248-257.
Moncaut, J.A. 2001. Inundaciones y sequías en la pampa bonaerense 1576-2000. Editorial El Aljibe, City Bell, Buenos Aires, 106 p.

Muhs, D.R., and Zárate, M.A. 2001. Eolian records of the Americas and their Paleoclimatic significance. In: V. Markgraf (Eds.), Interhemispheric Climate Linkages. Academic Press, San Diego, p. $183-216$.

Olivera, D., Grill, S., and Zavala, C. 2006. La transgresión holocena en Bahía Blanca. Análisis de facies y Palinología. $4^{\circ}$ Congreso Latinoamericano de Sedimentología y $11^{\circ}$ Reunión Argentina de Sedimentología (Bariloche), Actas: 158.

Pardiñas, U.F.J., and Tonni, E.P. 2000. A giant vampire (Mammalia, Chiroptera) in the Late Holocene from the Argentinean pampas: paleoenvironmental significance. Palaeogeography, Palaeoclimatology, Palaeoecology 160: 213-221.

Posamentier, H.W., and Allen, G.P. 1993. Variability of the sequence stratigraphic model: effects of local basin factors. Sedimentary Geology 86: 91-109.

Prieto, A. 1989. [Palinología de Empalme Querandies, provincia de Buenos Aires-Un modelo paleoambiental para el Pleistoceno tardio-Holoceno. Tesis Doctoral, Universidad Nacional de Mar del Plata, Mar del Plata, 207 p. Inédita.].

Prieto, A. 1996. Late Quaternary vegetational and climatic changes in the Pampa grassland of Argentina. Quaternary Research 45: $73-88$.

Prieto, A. 2000. Vegetational history of the Late glacial-Holocene transition in the grasslands of eastern Argentina. Palaeogeography, Palaeoclimatology, Palaeoecology 157: 167-188.

Quattrocchio, M., Borromei, A., Deschamps, C., Grill, S., and Zavala C. 2008. Landscape evolution and climate changes in the Late Pleistocene-Holocene, southern Pampa (Argentina): Evidence from palynology, mammals and sedimentology. Quaternary International 181: 123-138.

Quattrocchio, M., Deschamps, C., Martínez, D., Grill, S., and Zavala, C. 1988. Caracterización paleontológica y paleoambiental de sedimentos Cuaternarios, arroyo Napostá Grande, provincia de Buenos Aires. $2^{\circ}$ Jornadas Geológicas Bonaerenses (Bahía Blanca), Actas: 37-46.

Quattrocchio, M., Grill, S., and Zavala, C.1998. Cronosequence of paIynozones and cronostratigraphy chart from Napostá Grande creek, Buenos Aires province. Argentina. Quaternary of South America and Antartic Peninsula 11: 111-133.

Rabassa, J. 1989. Geología de depósitos del Pleistoceno Superior y Holoceno en las cabeceras del río Sauce Grande, provincia de Buenos Aires. $1^{\circ}$ Jornadas Geológicas Bonaerenses (Tandil), Actas: 765-790.

Rabassa, J., Brandani, A., Salemme, M., and Politis, G. 1989. La "Pequeña Edad de Hielo" (S. XVII a XIX) y su posible influencia en la aridización de áreas marginales de la Pampa Húmeda (provincia de Buenos Aires). $1^{\circ}$ Jornadas Geológicas Bonaerenses (Tandil), Actas: 559-577.

Reig, O. 1957. Diagnosis previas sobre los marsupiales de la Formación Arroyo Chasicó, Ameghiniana 1: 27-31.

Romero, E., and Fernández, C. 1981. Palinología de Paleosuelos del Cuaternario de los alrededores de Loberías (prov. Bs As). Ameghiniana 18: 273-285.

Sarjeant, W., Lacalli, T., and Gaines, G. 1987. The cysts and skeletal elements of dinoflagellates: speculations on the ecological causes for their morphology and development. Micropaleontology 33: 1-36.

Schultz, P.H., Zárate, M., Hames, B., Koeberl, C., Bunch, T., Storzer, D., Renne, P., and Wittkle, J. 2004. The Quaternary impact record from the Pampas, Argentina. Earth and Planetary Science 
Letters 219: 221-238.

Schumm, S.A. 1977. The Fluvial System. J. Wiley \& Sons, New York, $338 \mathrm{p}$.

Staplin, F.L., Jansonius, J., and Pocock, S.A.J. 1965. Evaluation of some Acritarchous Hystrichosphere Genera. Neues Jahrbuch für Geologie und Paläontologie Abhandlungen 123: 167-201.

Stoessel, L., Bogan, S., Martínez, G., and Agnolin, F. 2008. Implicaciones paleoambientales de la presencia del género Ceratophrys (anura, ceratophryinae) en contextos arqueológicos de la transición pampeano-patagónica en el Holoceno tardío (curso inferior del río Colorado, Argentina). Magallania 36: 195-203.

Stuiver, M., Reimer, P.J., and Reimer, R.W. 2005. CALIB 5.0 (programe an documentation). World Wide Web: http://calib.qub.ac.uk/calib/.

Stutz, S. 1996. Historia de la vegetación durante los últimos 5000 años de la albúfera Mar Chiquita, Buenos Aires, Argentina. TaIler Internacional: Potencial de los indicadores paleoambientales en la evaluación del impacto del Cambio Climático en los ecosistemas del Cono Sur de América del Sur (Canela, Brasil), 54 p.

Stutz, S., Prieto, A., and Isla, F. 1999. Cambio de la vegetación durante el Holoceno en el SE de la provincia de Buenos Aires: análisis polínico del arroyo La Ballenera. Publicación Especial de la Asociación Paleontológica Argentina 6: 65-69.

Tonni, E.P., Cione, A.L., and Figini, A.J. 1999. Predominance of arid climates indicated by mammals in the pampas of Argentina during the Late Pleistocene and Holocene. Palaeogeography, Palaeoclimatology, Palaeoecology 147: 257-281.

van Geel, B., Hallewas, D.P., and Pals, J.P. 1982-1983. A Late Holocene deposit under the Westfriese Zeedijik near Enkhuizen (prov. Of Noord-Holland, the Netherlands): palaeoecological and archaeological aspects. Review of Palaeobotany and Palynology 38: 269-335.

van Gell, B., and Aptroot, A. 2006. Fossil ascomycetes in Quaternary deposits. Nova Hedwigia 82: 313-329.

Verettoni, H. 1961. Las asociaciones halófilas del partido de Bahía Blanca. Bahía Blanca: Comisión Ejecutiva 150 aniversario de la Revolución de Mayo, 105 p.

Verettoni, H. 1965. Contribución al conocimiento de la vegetación psammofila de la región de Bahía Blanca. Diestra Producciones, Bahía Blanca, $160 \mathrm{p}$.

Verettoni, H., and Aramayo, E. 1976. Las comunidades vegetales de la Depresión del Salado (Provincia de Buenos Aires). Editorial Harris, Bahía Blanca, 175 p.

Verzi, D.H., Montalvo, C.I., and Deschamps, C.M. 2008. Biostratigraphy and biochronology of the Late Miocene of central Argentina: evidence from rodents and taphonomy. Geobios 41: $145-155$.
Verzi, D.H., Montalvo, C.I., and Tiranti, S.I. 2003. Un nuevo Xenodontomys (Rodentia, Octodontidae) del Mioceno tardío de La Pampa, Argentina. Patrón evolutivo y bioestratigrafía. Ameghiniana 40: 229-238.

Vilanova, I., Prieto, A., and Stutz, S. 2006. Historia de la vegetación de las llanuras costeras del este de la provincia de Buenos Aires durante el Holoceno. Ameghiniana 43: 147-159.

Wall, D., Dales, B., Lohmann, G.P., and Smith, W. 1977. The environmental and climatic distribution of dinoflagellate cysts in modern sediments from regions in the North and South Atlantic Oceans and adjacents seas. Marine Micropaleontology 2: 121-200.

Zárate, M.A. 1991. Late Pleistocene and Holocene landscape evolution in the southeastern Buenos Aires province, Argentina. Bamberger Geographische Schriftem Bd. 11, S.: 135-138.

Zárate, M.A., Kemp, R.A., Espinosa M., and Ferrero, L. 2000. Pedosedimentary and Palaeoenvironmental significance of a Holocene alluvial sequence in the southern Pampas, Argentina. The Holocene 10: 481-488.

Zavala, C., García, L., and Di Meglio, M. 2005. Redes de drenaje y paleoclimas en el Cuaternario del sur de la provincia de Buenos Aires. $16^{\circ}$ Congreso Geológico Argentino (La Plata), Actas en CD-ROM.

Zavala, C., Grill, S., Martínez, D., Ortiz, H., and González, R. 1992. Análisis paleoambiental de depósitos cuaternarios. Sitio Paleoicnológico Monte Hermoso I, provincia de Buenos Aires. $3^{\circ}$ Jornadas Geológicas Bonaerenses (La Plata), Actas: 31-37.

Zavala, C.A., and Quattrocchio, M.E. 2001. Estratigrafía y evolución geológica del río Sauce Grande (Cuaternario), provincia de Buenos Aires. Argentina. Revista de la Asociación Geológica Argentina 56: 25-37.

Doi: 10.5710/PEAPA.09.05.2016.84

Recibido: 1 de septiembre de 2015

Aceptado: 9 de mayo de 2016 